Cell Research (2000), 10, 139-149

\title{
Activation of phospholipase $D$ activity in transforming growth factor-beta-induced cell growth inhibition
}

\author{
Zhou Bing Hong, Jun Song Chen, Ming Qiang Chai, \\ Sheng Zhao, Jun Liang, He Hua Chen, Jian Guo \\ SonG* \\ State Key Laboratory of Molecular Biology, Shanghai Institute \\ of Biochemistry, Chinese Academy of Sciences, 320 Yue Yang \\ Road, Shanghai 200031, China
}

\begin{abstract}
Cells regulate phospholipase $\mathrm{D}$ (PLD) activity in response to numerous extracellular signals. Here, we investigated the involvement of PLD activity in transforming growth factor- $\beta$ (TGF-b1)-mediated growth inhibition of epithelial cells. TGF$\beta_{1}$ inhibits the growth of MDCK, Mv1Lu, and A-549 cells. In the presence of $0.4 \%$ butanol, TGF- $\beta_{1}$ induces an increase in the formation of phosphatidylbutanol, a unique product catalyzed by PLD. TGF-b also induces an increase in phosphatidic acid (PA) level in A-549 and MDCK cells. TGF- $\beta_{1}$ induces an increase in the levels of DAG labeled with $\left[{ }^{3} \mathrm{H}\right]$-myristic acid in A-549 and MDCK cells but not in Mv1Lu cells. No increase of DAG was observed in cells prelabeled with $\left[{ }^{3} \mathrm{H}\right]$-arachidonic acid. The data presented suggest that PLD activation is involved in the TGF- $\beta_{1}$-induced cell growth inhibition.
\end{abstract}

Key words: Transforming growth factor- $\beta$, phospholiapse $D$, signaling, phosphatidic acid, diacylglycerol.

\section{INTRODUCTION}

\footnotetext{
* Corresponding author. E-mail: songj@sunm.shcnc.ac.cn Abbreviations: PLD, Phospholipase D; PC, phosphatidylcholine; PIPs, phosphatidylinositol phosphates; PBut, phosphatidylbutanol; DAG, Diacylglycerol; PA, phosphatidic acid; TGF- $\beta_{1}$, Transforming growth factor- $\beta_{1}$.
} 
TGF- $\beta_{1}$ induced growth inhibition and PLD activation

PLD plays an important role in the membrane trafficking, endocytosis, cell growth, differentiation, inflammatory response, and other cellular functions[1]. The involvement and the regulation of PLD activity in the cellular processes have been intensively studied in the past decade. Altered PLD activity causes the change of the production of phosphatidic acid (PA), which may lead to further changes in the levels of other intracellular second messengers or lipid bioactive molecules through the metabolic conversion catalyzed by different enzymes. Phosphatidylcholine (PC)-specific PLD catalyzes the hydrolysis of PC and generates choline and PA, the latter can be further hydrolyzed to DAG by the action of a PA phosphatase. PA itself is an intracellular bioactive molecule, which is involved in the cell growth, differentiation, and other cellular functions[2],[3]. Lysophosphatidic acid (LPA), a potent signaling molecule which acts through G-protein coupled receptors, can be generated by the action of a phospholipase $\mathrm{A}_{2}$. It has been known that LPA is implicated in a variety of cellular functions[4],[5], including stimulation of cell proliferation and differentiation, $\mathrm{Ca}^{2+}$ mobilization, tumor cell invasion in vivo, chemotaxis, and other functions. The regulation of PLD activity and subsequent generation of different lipid signaling molecules is therefore a very important signaling event, which may be implicated in the interactions among different signaling pathways and in achieving the signaling specificity. PLD activity can be regulated by various factors, including PKC, GTP-binding proteins, $\mathrm{Ca}^{2+}$, ADP-ribosylation factors, ceramide, PIP2. [1],[6-8]. Many growth factors for receptor tyrosine kinases, including the epidermal growth factor (EGF), platelet-derived growth factor (PDGF), v-Src, fibroblast growth factor (FGF), and insulin-like growth factor (IGF), have been shown to activate PLD activity[9-14]. Activation of non-receptor tyrosine kinase v-Src has also been shown to activate PLD activity[15]. The involvement of protein kinase $\mathrm{C}$ in the regulation of PLD activity has been intensively studied in the past decade. Both PKC-dependent and -independent activation of PLD has been demonstrated.

TGF- $\beta$, a pleiotropic growth factor, is involved in the regulation of a variety of cell functions and physiological processes. It inhibits the growth of epithelial cells, promotes cell differentiation, and stimulates the extracellular matrix formation. TGF- $\beta$-mediated signaling is implicated in cell morphogenesis, body planning, wound healing, immunosuppression, and apoptosis[16],[17]. The receptors of TGF-b have been identified as the serine/ threonine kinases, which are comprised of three different types. The mechanism of the TGF-b-mediated signaling at the receptor level has been well characterized in the past several years. A major concern of the current studies in TGF- $\beta$ signaling area is the postreceptor signaling events and the interactions between different signaling components. The progress in this respect may provide insight into the mechanism for achieving the signaling specificity and diversity in TGF-b-mediated biological processes[18]. G proteins and MAPKs have been reported to be the downstream components of signaling mediated by TGF- $\beta$ family members. It is known that different type I receptor can interact with a single type II receptor[19]. Studies on the TGF- $\beta$ receptor-interacting proteins and the cloning and functional characterization of a family of Smad proteins in the last few years 
increased our understanding of the TGF- $\beta$-mediated signaling pathway[20-22]. Activation of receptor serine-threonine kinase activity leads to the phosphorylation of specific Smad proteins and translocation of heteromeric Smad protein complexes to the nucleus. Smads can associate with various nuclear transcription factors, and themselves have DNA binding capability and transcriptional transactivation activity. Once in the nucleus, Smads function in the activation or suppression of the transcription of specific target genes. Smadsmediated signaling is implicated in cell growth, differentiation, and apoptosis. It is not clear if other signaling molecules are involved in the downstream signaling of TGF- $\beta$. The involvement and significance of the lipid signaling events in the TGF- $\beta$-mediated cell growth inhibition also remains to be identified. Here we studied the effects of TGF- $\beta_{1}$ on the PLD activity and the formation of DAG in several lines of epithelial cells whose growth can be inhibited by TGF- $\beta$.

\section{MATERIALS AND METHODS}

\section{Materials}

A-549 (Human lung epithelial cancer cells), MDCK (Madin Darby Canine Kidney cells) and Mv1Lu (Mink lung epithelial cells) were obtained from ATCC (American Type Culture Collection). Cell culture reagents and medium were purchased from GIBCO. $\left[9,10-{ }^{3} \mathrm{H}\right]$-myristic acid $(12.5 \mathrm{Ci} /$ $\mathrm{m} \mathrm{M})$ and $\left[{ }^{3} \mathrm{H}\right]$-arachidonic acid $(100 \mathrm{Ci} / \mathrm{M})$ were obtained from NEN Life Science Products (Boston, MA). $\left[{ }^{3} \mathrm{H}\right]$-serine $(1.04 \mathrm{TBq} / \mathrm{M}),\left[{ }^{3} \mathrm{H}\right]$-thymidine $(3.00 \mathrm{TBq} / \mathrm{M})$ were obtained from Amersham Life Science (Buckinghamshire, UK). EGF (human, recombinant) was from CALBIOCHEMR (San Diego, CA). Phosphatidylbutanol (PBut) standard was from Avanti Polar Lipids (Alabaster, AL). 1-butanol was from Aldrich Chemical Company, Inc. (Milwaukee, WI). Silica Gel $60 \AA$ thin layer chromatography (TLC) plates were from Whatman (Clifton, NJ). All other reagents were from Sigma unless otherwise indicated. EN ${ }^{3}$ HANCE spray was purchased from Du Pont-New England Nuclear (NEN) Life Science Products (Boston, MA).

\section{Methods}

\section{Cell Culture and labeling}

A-549 cells were cultured in F-12K medium containing $10 \%$ new born calf serum. MDCK cells were cultured in MEM with Earle' s BSS containing $5 \%$ NCS, $5 \%$ FCS. Mv1Lu cells were cultured in MEM with Earle' $\mathrm{s}$ BSS and nonessential amino acid containing $5 \%$ NCS, $5 \%$ FCS. All cell cultures contain penicillin $(100 \mathrm{U} / \mathrm{ml}) /$ streptomycin $(100 \mu \mathrm{g} / \mathrm{ml})$. Cells were grown in $60 \mathrm{~mm}$ plate at $37^{\circ} \mathrm{C}$, under $5 \% \mathrm{CO}_{2}$. For measuring the PLD activity or the DAG/PA derived from phosphatidylcholine, 80-90\% confluent cell cultures were made quiescent by maintaining cells in $1.5 \mathrm{ml}$ DMEM containing $0.5 \%$ newborn calf serum for $24 \mathrm{~h}$. The cells were then labeled with 3-4 $\beta \mathrm{Ci}\left[{ }^{3} \mathrm{H}\right]$-myristic acid overnight. For measuring the DAG derived from phosphatidylinositol phosphates, cells were labeled with $2 \mu \mathrm{Ci}\left[{ }^{3} \mathrm{H}\right]$-arachidonic acid overnight. When necessary, the original labeling materials were concentrated through Speed-Vac concentrator to make the final ethanol concentration in the medium less than $0.1 \%$.

\section{Determination of PLD activity and the production of DAG}

Lipids were extracted and analyzed as previously described[15] with minor modifications. Reactions were stopped by quickly pouring off the medium and treating the cells with $600 \mu \mathrm{l}$ of ice-cold $\mathrm{CH}_{3} \mathrm{OH} /{ }_{6} \mathrm{~N} \mathrm{HCl}$ (50:2, v:v). Samples were carefully scraped and moved into Eppendorf 
TGF- $\beta_{1}$ induced growth inhibition and PLD activation

tubes and extracted with the same volume of ice-cold $\mathrm{CHCl}_{3}$. Phase separation was made by adding $200 \mu \mathrm{l}$ of $\mathrm{NaCl}$ solution (1M), mixed and votexed. The organic phase was transferred to another Eppendorf tube and re-extracted with ice-cold $\mathrm{NaCl}(0.35 \mathrm{M}, 600 \mu \mathrm{l})$ and $\mathrm{CH} 3 \mathrm{OH} / 6 \mathrm{~N} \mathrm{HCl}(50: 2$, $\mathrm{v}: \mathrm{v}, 200 \mu \mathrm{l})$. The organic phase was dried by Speed-Vac concentrator. Extracted lipid samples were redissolved in 30-40 $\mu \mathrm{l}$ of $\mathrm{CHCl}_{3} / \mathrm{CH}_{3} \mathrm{OH}$ (95:5) and applied to Silica-gel 60^ TLC plate. The lipids were separated by different solvent systems: For PA and PBut, the upper phase of ethylacetateisooctane-acetic acid-water (90:50:20:100, solvent system I); for DAG and monoacylglycerol MG, hexane:diethylether:methanol:acetic acid (90:20:3:2, solvent system II). For PA, PBut, MG, and DAG, lipid samples were separated twice with solvent system I (at each time, chromatography was stopped when the solvent front reaches the middle of the TLC plate) and once with the solvent system II. The plate was lightly stained with iodine vapour and the standard lipids were marked. Plate was sprayed with $\mathrm{EN}^{3} \mathrm{ANCE}$ spray and exposed by autoradiography with a Kodak film at $-80^{\circ} \mathrm{C}$. Specific lipids were identified with the references of the migration of lipid standards and were scrapped from TLC plates into scintillation vials. Lipids were eluted out of the silica gel by adding $0.5 \mathrm{ml} \mathrm{CH}_{3} \mathrm{OH}$ and then mixed with $2.5 \mathrm{ml}$ Biodegradable Counting Scintillant (BCS, Amersham), the radioactivity was measured by liquid scintillation spectrometry.

\section{Determination of the production of inositol phosphates}

80-90\% confluent A-549 cells grown in $60 \mathrm{~mm}$ plates were incubated in serum-deprived F-12K medium (containing $0.5 \% \mathrm{BSA}$ ) for two hours. Cells were then labeled with $1 \mu \mathrm{Ci}\left[{ }^{3} \mathrm{H}\right]$-myo-inositol in serum-deprived inositol-free F-12K medium (containing $0.5 \% \mathrm{BSA}$ ) for $24 \mathrm{~h}$. Cell were washed with PBS and incubated in the same medium without $\left[{ }^{3} \mathrm{H}\right]$-myo-inositol for 50 minutes, and then treated with TGF- $\beta_{1}$ for the indicated times in the presence of $20 \mathrm{~m}$ M lithium chloride, which was added $10 \mathrm{~min}$ before the TGF- $\beta_{1}$. The reaction was stopped and the inositol phosphates were extracted as described by Hawkins et al.[23].

\section{Growth inhibition assay}

Cells were grown in 24 -well plate to about $80 \%$, then incubated in $0.5 \mathrm{ml}$ respective medium containing $0.5 \% \mathrm{NCS}$ for additional $30 \mathrm{~h}$. TGF- $\beta_{1}$ was added at different time points during the incubation. To label the cells, $\left[{ }^{3} \mathrm{H}\right]$-thymidine $(0.1(\mathrm{Ci} / \mathrm{ml})$ was added during the last $4 \mathrm{~h}$ of incubation. The incubation was terminated by pouring off the medium and washing the cells with ice-cold phosphate-buffered saline (PBS) for 3 times followed by adding $0.5 \mathrm{ml}$ of $10 \%$ trichloroacetic acid (TCA). The plates were maintained on ice for 20 minutes and washed again with ice-cold deionized water for 3 times. The acid-insoluble material was redissolved in $0.4 \mathrm{ml}$ lysis buffer ( $1 \% \mathrm{SDS}, 0.2 \mathrm{~N} \mathrm{NaOH})$ and moved into scintillation vials, mixed with 2.5 volume of BCS. The DNA-associated $\left[{ }^{3} \mathrm{H}\right]$-radioactivity was determined by liquid-scintillation spectrometry.

\section{RESULTS AND DISCUSSION}

\section{Growth inhibitory effects of TGF- $\beta$ on Mv1Lu, MDCK, and A-549 cells}

Dysregulation of TGF- $\beta$ signaling is linked with carcinogenesis, tumor invasion, immune diseases, and other abnormalities[16],[17]. The downstream signaling mechanism of TGF- $\beta$-mediated inhibition of cell growth and other physiological effects has been a focus of some studies. In this study, we determined the effects of TGF- $\beta_{1}$ on the growth of several epithelial cell lines. Fig 1 showed that TGF $\beta_{1}$ strongly inhibited the DNA synthesis of Mv1Lu, MDCK, A-549 cells in a time-dependent manner. Inhibition is maximal at the concentration of $5 \mathrm{ng} / \mathrm{ml}$ (data not shown). The inhibitory effect of TGF $\beta_{1}$ on DNA synthesis of A-549 cells is not as strong as its effects found in Mv1Lu and MDCK cells. 
In addition, a refractory response of A-549 cells on the prolonged TGF- $\beta_{1}$ treatment (usually after $2 \mathrm{~d}$ ) was observed. These results indicate that TGF- $\beta_{1}$ has a different potency on the inhibition of the growth of Mv1Lu, MDCK, and A-549 cells. The results are also consistent with our observation obtained through the microscope and the crystal violet assay. Unlike the Mv1Lu and MDCK cells, A-549 is a type of cancer cells. The reduced sensitivity of A-549 cells to TGF- $\beta$ treatment may account in certain extent the malignancy of these cells. Thus, investigating the signaling mechanism through which TGF-b1 differentially inhibits the growth of these cells may be helpful in the understanding of how cancer cells escape from normal growth controls.

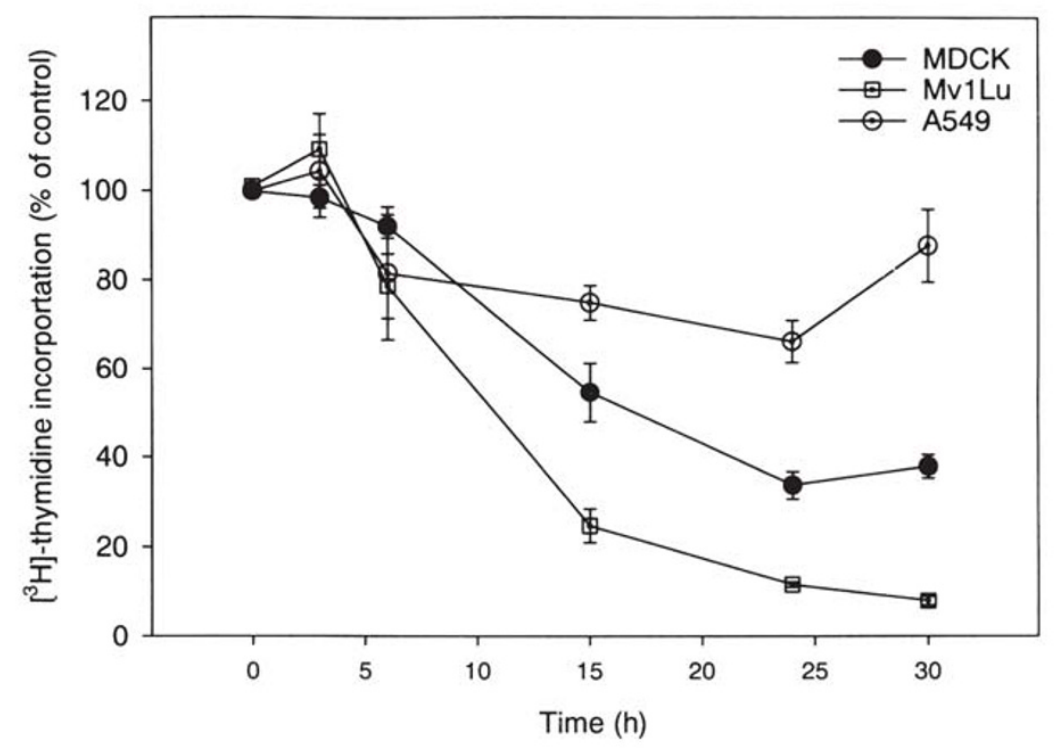

Fig 1.

Effect of TGF- $\beta_{1}$ on DNA synthesis in MDCK, Mv1Lu, and A-549 cells. Quiescent cells grown in $35 \mathrm{~mm}$ plates were stimulated with TGF-b1 (5 ng/ml) for the indicated time, then labeled with $\left[{ }^{3} \mathrm{H}\right]$-thymidine $(0.2 \mu \mathrm{Ci} / \mathrm{ml})$ during the last $4 \mathrm{~h}$ of incubation. The data are the means $\pm \mathrm{SD}$ of a representative from three experiments done in quadruplicates.

TGF- $\beta_{1}$ induces the activation of PLD activity in Mv1Lu, MDCK, and A-549 cells

It has been reported in recent years that Smads and MAP kinases play important roles in TGF- $\beta$-mediated cellular signaling and the associated biological events. Very little is known about the implications of lipid signaling pathways in TGF- $\beta$-mediated growth inhibition. It has been reported that TGF-b increases the activity of PA phosphatase- 1 in rat hepatocytes[24]. To investigate whether the lipid signaling events are involved in the TGF- $\beta_{1}$-mediated cell growth inhibition, we determined the PLD activity in response to the TGF- $\beta_{1}$ treatment. In the presence of primary alcohol, PLD also catalyzes the transphosphatidylation reaction, resulting in the formation of phosphatidylalcohol, a 
TGF- $\beta_{1}$ induced growth inhibition and PLD activation

unique product of PLD, which has been widely used for examining the PLD activity[25]. Cells were labeled with $\left[{ }^{3} \mathrm{H}\right]$-myristate, which preferentially incorporated into the $\mathrm{PC}$, and then treated with TGF- $\beta_{1}$ in the presence of butanol. PLD activity was determined as measured by the formation of PBut. As shown in Fig 2, treatment of MDCK, Mv1Lu, and A-549 cells with TGF- $\beta_{1}$, resulted in a slow but persistent increase of PBut in these cells, which could be detected after $2 \mathrm{~h}$ and does not decrease within the $16 \mathrm{~h}$ of incubation. These results suggest that increased PLD activity may be involved in the TGF $\beta_{1}$-induced inhibition of cell growth. In other experiments, we also found that TGF- $\beta_{1}$ stimulates PLD activity in A-431 cells (data not shown). Since TGF $\beta_{1}$-induced growth inhibition and apoptosis of cells require the synthesis of new proteins and TGF- $\beta_{1}$-induced gene expression (manuscript submitted), PLD activation may likely to be regulated by an intermediary component in TGF- $\beta$ induced signaling events. However, the specific function of PLD in TGF- $\beta_{1}$-mediated biological events has to be characterized.

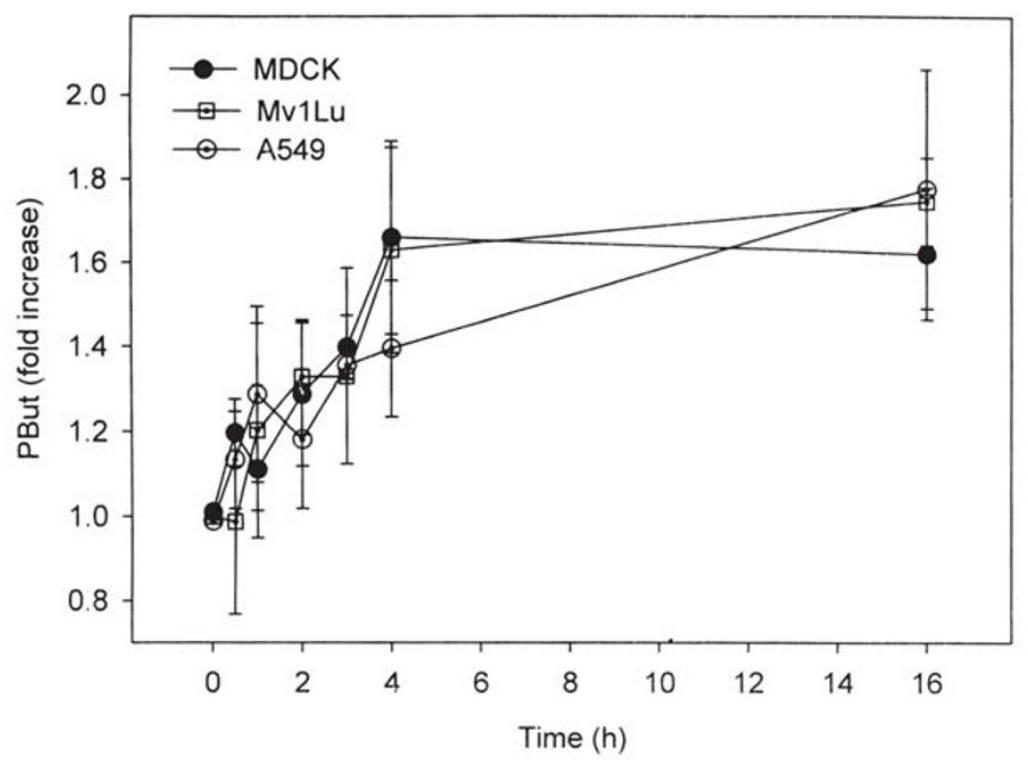

Fig 2.

Effect of TGF- $\beta_{1}$ on PLD activity. $\left[{ }^{3} \mathrm{H}\right]$-myristic acid-labeled cells grown in 60 $\mathrm{mm}$ plates were stimulated with TGF-b1 $(5 \mathrm{ng} / \mathrm{ml})$ for the indicated time in the presence of $0.4 \%$ of butanol. The lipids were extracted and analyzed as described in "Materials and Methods" section. PLD activity was determined as measured by the formation of PBut. The data are the means \pm SD of 3 independent done in duplicates. All values were normalized to respective nontreated controls which were designed as 1 fold.

In Fig 3, a corresponding increase in the PA level in MDCK cells treated with TGF- 
Zhou BH et al.

$\beta_{1}$ was shown. The increase of PA level in A-549 cells is not as obvious as that of the PBut, and no increase of PA was detected in Mv1Lu cells. The discrepancy between the increase of PBut and the PA is probably due to the fact that the metabolic conversion of PA in the cells is rapid, and the rates of metabolic conversion of PA are likely to be different in different cells. The changes in the PA production are thus more difficult to be accurately detected as compared with that of the PBut. It is believed that TGF- $\beta$ does not interfere with the early signaling events induced by growth factors. In our studies, no effect of TGF- $\beta$ on the fetal calf serum-, EGF-, and PMA-induced activation of PLD was observed.

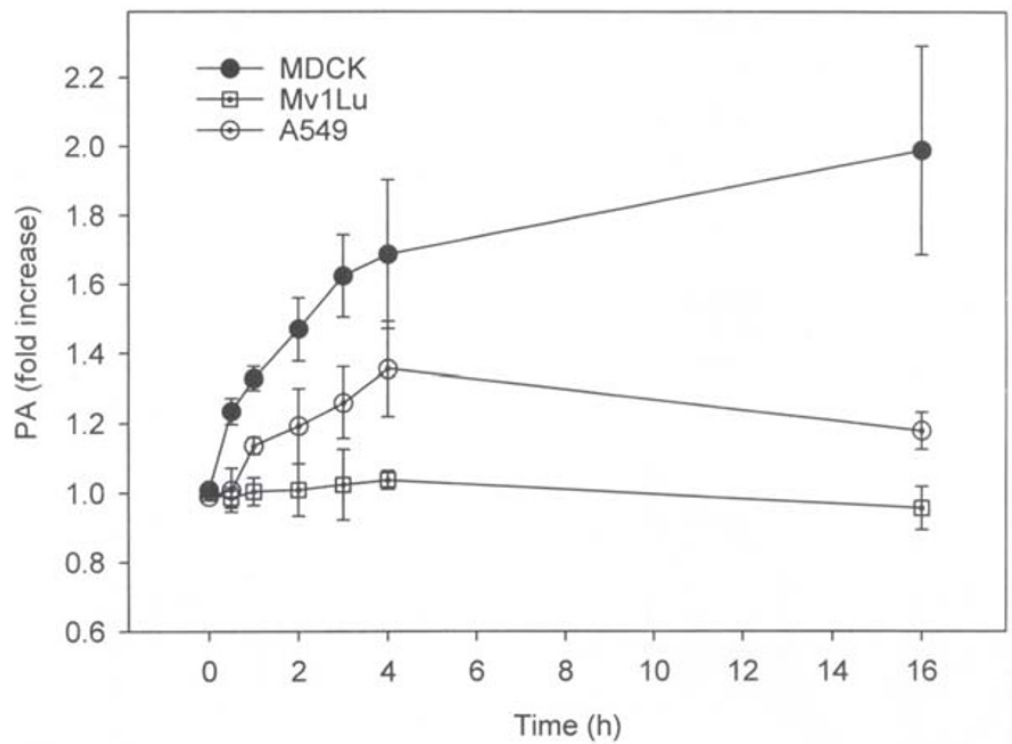

Fig 3.

\section{Fig 3.}

Effect of TGF- $\beta_{1}$ on the intracellular level of PA $\left[{ }^{3} \mathrm{H}\right]$-myristic acid-labeled cells were stimulated with TGF- $\beta_{1}$ in the absence of butanol. The lipids were extracted and PA was measured as described in "Materials and Methods" section. The data are the means $\pm \mathrm{SD}$ of 3 independent experiments done in duplicates. All values were normalized to respective nontreated controls.

\section{Effects of TGF- $\beta_{1}$ on the PC-and PIPs-derived DAG formation}

Altered PLD activity could influence the level of intracellular second messenger DAG, which is formed through PA phosphatase-catalyzed hydrolysis of PA. DAG plays an important role in cellular growth and other functions, which acts as a physiological activator for some PKC isoforms[26] and has been shown to be a direct $\mathrm{Ca}^{2+}$ ion channel regulator[27]. Though it has been reported that PC-PLC are involved in the TGF- $\beta_{1}-$ mediated signaling or growth inhibition[28],[29], the effects of TGF- $\beta$ on the phospholipase activity and the DAG production has not been determined. To investigate whether the TGF- $\beta$-mediated increase of PLD activity leads to concomitant increase in the level of DAG, we determined the formation of PC-derived DAG labeled by $\left[{ }^{3} \mathrm{H}\right]$-myristate. As 
TGF- $\beta_{1}$ induced growth inhibition and PLD activation

shown in Fig 4, a gradual increase in the production of DAG induced by TGF- $\beta_{1}$ was observed in MDCK cells. TGF- $\beta_{1}$ only slightly increases the DAG production in A-549 cells. Whereas, no increase of DAG production was detected in Mv1Lu cells. DAGs generated from PIPs and PC have different biological properties, which suggests a different biological significance[12]. In this study, we also determined the effect of TGF- $\beta$ on the production of DAG derived from PIPs. As shown in Fig 5, TGF- $\beta$ does not stimulate the formation of PIPs-derived DAG in the cells examined. Only a very weak increase in TGF$\beta_{1}$-treated A-549 cells was observed. Consistent with these results, similar results were obtained on the TGF-b1-stimulated production of inositol phosphates in A-549 cells labeled with $\left[{ }^{3} \mathrm{H}\right]$-inositol (data not shown). The results indicate that phosphatidylinositol specific phospholipase $\mathrm{C}$ is not involved in the TGF- $\beta$-mediated growth inhibition in these cells.

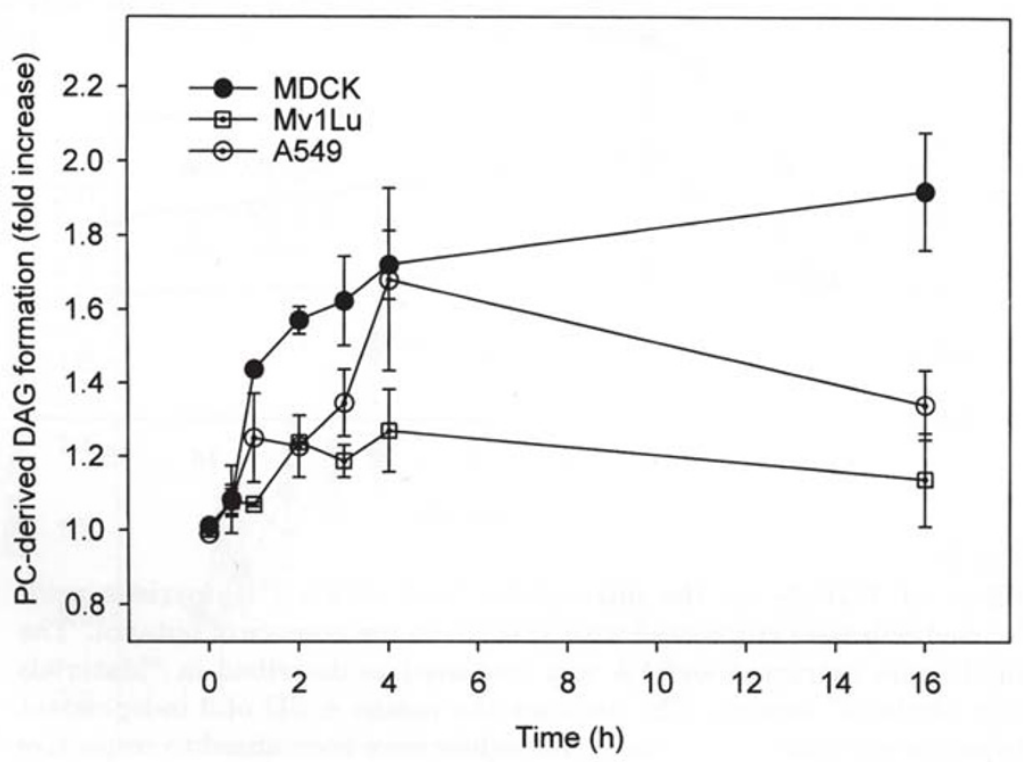

Fig 4.

Effect of TGF- $\beta_{1}$ on the intracellular level of PC-derived DAG. Quiescent cells grown in $60 \mathrm{~mm}$ plates were labeled with [ $\left.{ }^{3} \mathrm{H}\right]-\mathrm{MA}$ for $16 \mathrm{~h}$ and treated with TGF- $\beta_{1}(5 \mathrm{ng} /$ $\mathrm{ml}$ ) for indicated time. The lipids were extracted and DAG was measured as described in "Materials and Methods". The data are the means \pm SD of 3 independent experiments done in duplicates. All values were normalized to respective nontreated controls. MA, myristic acid.

It is not clear whether the different effects of TGF- $\beta_{1}$ on the PA and DAG levels of these cells result from the cell-specificity or the differential metabolic conversion of PA. Though all of the three cell lines used in this study are epithelial cells, they were from different 
species and different tissues. Mv1Lu is a mink lung epithelial cell line, whose growth can be most easily inhibited by TGF- $\beta$. As a canine kidney cell line, MDCK has a distinct polarized cellular structure, whereas, A-549 cells are derived from human lung carcinomatous tissure. The observation that human TGF-b1 increases the PLD activity in these three different cells suggests that PLD is one of the components of TGF- $\beta$-induced signaling pathway. The precise relationships between the TGF- $\beta$-induced activation and its anti-proliferate effect also remain unidentified. In summary, the present study demonstrates that TGF- $\beta$ increases the PLD activity in MDCK, A-549, and Mv1Lu cells. Corresponding increases of PA and PC-derived DAG levels were also observed in MDCK and A-549 cells. The data indicate that PLD activation is involved in TGF- $\beta_{1}$-induced growth inhibition in these cells. Since PA itself is an intracellular second messenger and the metabolic conversion of PA can generate different lipid signaling molecules, further characterization of the roles of PLD activity is therefore important in a better understanding of the mechanisms through which TGF- $\beta$ regulates cell growth, differentiation, and apoptosis.

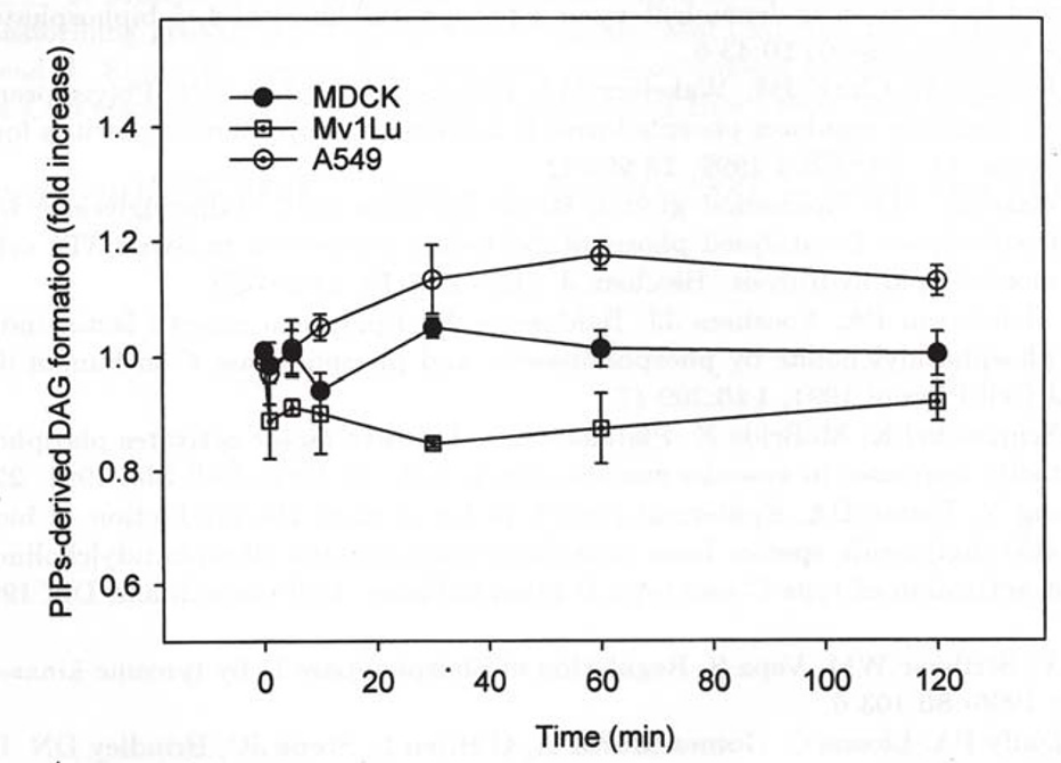

Fig 5.

Effect of TGF- $\beta$ on the intracellular level of PIPs-derived DAG. Quiescent cells grown in $60 \mathrm{~mm}$ plates were labeled with $\left[{ }^{3} \mathrm{H}\right]$-AA for $16 \mathrm{~h}$. DAG was extracted and measured as described in Fig 4 . The data are the means \pm SD of 2 independent experiments (one experiment was performed in duplicates, another one was performed in triplicates). All values were normalized to respective nontreated controls. AA, arachidonic acid.

\section{ACKNOWLEDGEMENT}

We thank Dr. Jinhui LIAO for helpful discussi ons. We are grateful to Dr. Rik 
TGF- $\beta_{1}$ induced growth inhibition and PLD activation

DERYNCK for providing the TGF- $\beta_{1}$. This work was supported by the Chinese Academy of Sciences (KJ951-B1-608 and "100 Projects Program"), The National Natural Science Foundation, No. 396250007 and 39870396).

\section{REFERENCES}

[1] Gom é z-Cambronero J, Keire P. Phospholipase D: a novel major player in signal transduction. Cell Signal 1998; 10:387-97.

[2] English D. Phosphatidic acid: a lipid messenger involved in intracellular and extracellular signalling. Cell Signal 1996; 8:341-7.

[3] Nakashima S. Nozawa Y. Possible role of phospholipase D in cellular differentiation and apoptosis. Chem Phys Lipids 1999; 98:153-64.

[4] Moolenaar WH, Kranenburg O, Postma FR, Zondag GC. Lysophosphatidic acid: G-protein signaling and cellular responses. Curr Opin Cell Biol 1998; 9:168-73.

[5] Nietgen GW. Durieux, ME. Intercellular signaling by lysophosphotidate. Cell Adhes Commun 1998; 5: 221-35.

[6] Exton JH. Regulation of phospholipase D. Biochim Biophys Acta 1999; 1439:121-33.

[7] Hodgkin MN, Masson MR, Powner D, Saqib KM, Ponting CP, Wakelam MJ. Phospholipase D regulation and localization is dependent upon a phosphatidylinositol 4, 5-biphosphate-specific PH domain. Curr Biol 2000; 10:43-6.

[8] Levy BD, Fokin VV, Clark JM, Wakelam MJ, Petasis NA, serhan CN. Polyisoprenyl phosphate (PIPP) signaling regulates phospholipase D activity: a 'stop' signaling switch for aspirin-triggered lipoxin A4. FASEB J 1999; 13:903-11.

[9] Cook SJ, Wakelam MJ. Epidermal growth factor increases sn-1, 2-diacylglycerol levels and activates phospholipase D-catalysed phosphatidylcholine breakdown in Swiss 3T3 cells in the absence of inositol-lipid hydrolysis. Biochem J 1992; 285(Pt 1):247-53.

[10] Fisher GJ, Henderson PA, Voorhees JJ, Baldassare JJ. Epidermal growth factor-induced hydrolysis of phosphatidylcholine by phospholipase D and phospholipase C in human dermal fibroblasts. J Cell Physiol 1991; 146:309-17.

[11] Welsh CJ, Schmeichel K, McBride K. Platelet-derived growth factor activates phospholipase D and chemotactic responses in vascular smooth muscle cells. In Vitro Cell Biol 1991; 27:425-31.

[12] Song J, Jiang Y, Foster DA. Epidermal growth factor induces the production of biologically distinguishable diglyceride species from phosphatidylinositol and phosphatidylcholine via the independent activation of type $\mathrm{C}$ and type D phospholipase. Cell Growth and Diff 1994; 5:79-85.

[13] Natarajan V, Scribner WM, Vepa S. Regulation of phospholipase D by tyrosine kinases. Chem Phys Lipids 1996; 80:103-6.

[14] Martin A, Duffy PA, Liossis C, Gomez-Mu?oz A, O'Brien L, Stone JC, Brindley DN. Increased concentrations of phosphatidate, diacylglycerol and ceramide in ras- and tyrosine kinase (fps)-transformed fibroblasts. Oncogene 1997; 14:1571-80.

[15] Song J, Pfeffer LM, Foster DA. v-Src increases diacylglycerol levels via a type D phospholipase mediated hydrolysis of phosphatidylcholine. Mol Cell Biol 1991; 11:4903-8.

[16] Padgett RW. TGF-beta signaling pathways and human diseases. Cancer Metastasis Rev 1999; 18:24759. Review.

[17] Kelly DL, Rizzino A. Growth regulatory factors and carcinogenesis: the roles played by transforming growth factor beta, its receptors and signaling pathways. Anticancer Res 1999; 19(6A):4791-807. Review.

[18] Piek E, Heldin CH, Ten Dijke P. Specificity, diversity, and regulation in TGF-beta superfamily signaling. FASEB J 1999; 13:2105-24. Review. 


\section{Zhou BH et al.}

[19] Derynk R, Feng XH. TGF- $\beta$ receptor signaling. Biochim Biophys Acta 1997; 1333:F105-50.

[20] Verschueren K, Huylebroeck D. Remarkable versatility of Smad proteins in the nucleus of transforming growth factor-beta activated cells. Cytokine Growth Factor Rev 1999; 10:187-99. Review.

[21] Wrana JL. Regulation of Smad activity. Cell 2000; 100:189-92. Review.

[22] Heldin CH, Migazono K, and ten Dijke P. TGF- $\beta$ signaling from cell membrane to nucleus through smad proteins. Nature 1997; 390:465-71.

[23] Hawkins PT, Stephens L, Downes CP. Rapid formation of inositol 1, 3, 4, 5-tetrakisphosphate and inositol 1, 3, 4-trisphosphate in rat parotid glands may both result indirectly from receptor-stimulated release of inositol 1, 4, 5-trisphosphate from phosphatidylinositol 4, 5-bisphosphate. Biochem J 1986; 238:507-16.

[24] Dixon MC, Yeaman SJ, Agius L, Day CP. Transforming growth factor $\beta$ increases the activity of phosphatidate phosphohydrolase-1 in rat hepatocytes. Biochim Biophys Res Comm 1997; 230:365-9.

[25] Morris AJ, Frohman MA, Engebrecht J. Measurement of phospholipase D activity. Anal Biochem 1997; 252:1-9. Review.

[26] Newton AC. Regulation of protein kinase C. Curr. Opin. Cell Biol 1999; 9:161-7.

[27] Hofmann T, Obukhov AG, Schaefer M, Harteneck C, Gudermann T, Schultz G. Direct activation of human TRPC6 and TRPC3 channels by diacylglycerol. Nature 1999; 397:259-630.

[28] Diaz-Meco MT, Dominguez I, Sanz L, Municio MM, Berra E, Gornet ME, DE Herretos AG, Johansen T, Moscat J. Phospholipase C-mediated hydrolysis of phosphatidylcholine is a target of transforming growth factor $\beta_{1}$ inhibitory signals. Mol Cell Biol 1991; 12:302-308.

[29] Halstead J, Kemp K, Ignotz RA. Evidence for involvement of phospholipase C and protein kinase C in transforming growth factor $\beta$ signaling. J Biol Chem 1995; 270:13600-3.

Received April-27-2000. Revised May-10-2000. Accepted May-15-2000. 